\title{
Record of Carineta Amyot and Audinet-Serville, 1843 (Hemiptera: Cicadidae: Cicadettinae: Carinetini) in Goiás State, Brazil
}

\author{
Douglas Henrique Bottura Maccagnan * \\ Alan Ricardo Souza Gomes \\ Hiago Costa Dias \\ Millena Oliveira Duarte
}

\author{
Laboratório de Entomologia, Universidade Estadual de Goiás, Câmpus Iporá \\ Avenida R2 Qd1, s/nº, Bairro Novo Horizonte 2, CEP 76200-000, Iporá - GO, Brasil \\ * Autor para correspondência \\ douglas.hbm@ueg.br
}

Submetido em 12/03/2018

Aceito para publicação em 10/09/2018

\section{Resumo}

Registro de Carineta Amyot e Audinet-Serville, 1843 (Hemiptera: Cicadidae: Cicadettinae: Carinetini) no Estado de Goiás, Brasil. Cigarras (Hemiptera: Cicadidae) são insetos caracterizados principalmente pelo som que emitem, o que torna sua presença evidente em áreas naturais e urbanas. Além disso, sabemos pouco sobre as espécies que ocorrem na região neotropical, inclusive no Brasil. Este é o primeiro relato de espécies de Carineta no estado de Goiás, Brasil. As coletas foram feitas com armadilhas luminosas em duas localidades próximas na área central do bioma Cerrado. Foram amostradas as espécies Carineta durantoni Boulard, 1986, C. gemella Boulard, 1986, C. rufescens (Fabricius, 1803) e C. spoliata (Walker, 1858). Imagens dessas espécies e sua distribuição atual são apresentadas aqui.

Palavras-chave: Biogeografia; Cerrado; Cicadoidea; Distribuição; Insecta

\section{Abstract}

Cicadas (Hemiptera: Cicadidae) are insects characterized mainly by the sound they emit, which makes their presence evident in natural and urban areas. Beyond this, we know little about the species that occur in the neotropical region, including Brazil. This is the first report of species of Carineta in Goiás State, Brazil. The collections were made with light traps in two close localities in the core area of the Cerrado biome. We sampled the species Carineta durantoni Boulard, 1986, C. gemella Boulard, 1986, C. rufescens (Fabricius, 1803) and C. spoliata (Walker, 1858). Images of these species and their current distribution are presented here.

Key words: Biogeography; Cerrado; Cicadoidea; Distribution; Insecta 
Cicadas are insects characterized mainly by the presence of a sound-producing organ in the male. There are more than 3,000 species worldwide (SANBORN, 2013), and Brazil is currently known to harbor 158 species distributed in 33 genera (SANBORN 2016a; 2017a; RUSCHEL; CARVALHO, 2018). The Carinetini are characterized as follows: the pronotum distinctly narrowed anteriorly, never longer than the mesonotum, sometimes much shorter; the lateral pronotal margins are oblique, not ampliate; the body being more or less robust, narrowed towards the head and apex of abdomen, which is sometimes very short; tegmina and wings hyaline, the former being in a few cases semiopaque, but usually clear, and frequently unspotted (DISTANT, 1905). Included in the Carinetini are eight genera, of which seven are restricted to the neotropical region (Ahomana Distant, 1905; Carineta Amyot \& Audinet-Serville, 1843, Guaranisaria Distant, 1905, Herrera Distant, 1905, Novemcella Goding, 1925, Paranistria Metcalf, 1952 and Toulgoetalna Boulard, 1982) and the other (Karenia Distant, 1888) occurring in China and Thailand (SANBORN, 2013; 2014).

Carineta is the richest genus of cicadas in the neotropical region, and this genus of the Carinetini is the only one with representives in Brazil. In this genus, 76 species have been recorded, distributed from Mexico to Central America and all South America (SANBORN, 2013 ; 2017b). Carineta can be distinguished from the other genera of the tribe by the following: the fore wing much longer than the body and with greatest width about one-third the length; head (including eyes) more or less narrower than base of the mesonotum; front about as long or a little longer than vertex; pronotum considerably shorter than mesonotum; and abdomen about as long as space between apex of head and base of cruciform elevation (DISTANT, 1906). Twenty-two species of Carineta are recorded for Brazil (RUSCHEL; CARVALHO, 2018). However, there is lack information about their general ecology, including distribution in the country. Therefore, the aim of the present work was to record for the first time the occurrence of four species of Carineta in Goiás State, Brazil.

The cicadas were collected by the use of four light traps with compact fluorescent lamps (4u, 46W,
$6500 \mathrm{~K})$ in the neighboring municipalities of Diorama (16 $\left.{ }^{\circ} 14^{\prime} \mathrm{S}, 51^{\circ} 16^{\prime} \mathrm{W}\right)$ from Septenber 2011 to February 2014 and Israelândia $\left(16^{\circ} 21^{\prime} \mathrm{S}, 51^{\circ} 00^{\prime} \mathrm{W}\right)$ from August 2016 to January 2018. The insects were collected under a permit from Instituto Chico Mendes de Conservação da Biodiversidade (ICMBio), license number 51649-1. During the collection period, the light traps were set up for two consecutive nights, twice a month. The distance between the two sampling sites was about 30 $\mathrm{km}$. These municipalities are located in the core of the Cerrado biome (Brazilian savanna) and the climate is characterized by a dry season from May to September and a wet season from October to April (Köppen Aw - tropical savanna climate) (ALVES, 2011).

The identification of the species was based on the literature (BOULARD, 1986; MARTINELLI; ZUCCHI, 1989 ; 1997) and by comparison with previously identified specimens. Some species of Carineta form groups that are very similar morphologically, making it necessary to analyze the male genitalia to confirm some identification (BOULARD, 1986; CHAMPANHET, 1999). When necessary, the male genitalia were cut off and heated in a double-boiler in 5\% $\mathrm{KOH}$ until clarified. Subsequently the genitalia were washed in distilled water and placed in Eppendorf-type plastic tubes containing $60 \%$ glycerin. The survey of occurrence sites was based on the catalogs of Metcalf (1963), Duffels and Van der Laan (1985), Sanborn (2013), Ruschel and Carvalho (2018) and latest publications (BARRETO; PORFIRO, 2015; SANBORN, 2016b; 2017b). The distribution map was made using the SimpleMappr (SHORTHOUSE, 2010). Voucher material of the cicadas collected is deposited in the Entomological Collection of the Universidade Estadual de Goiás - Câmpus Iporá (CE-UEG).

Although there are many species of Carineta distributed throughout a large area of Brazil, no species of this genus has been previously reported in Goiás. In our field work, we collected four species belonging to Carineta as follows:

- Carineta durantoni Boulard, 1986 (Figure 1A) - We collected one male of $C$. durantoni in the municipility of Israelândia on April 2017. The occurrence of this species has been recorded in 
French Guiana (BOULARD, 1986; SANBORN, 2013) and previously in Brazil only in Rondônia State (SANBORN, 2008) (Figure 2).
- Carineta gemella Boulard, 1986 (Figure 1B) - In all, 90 male specimens and only one female of $C$. gemella were collected. This species was abundant

FIGURE 1: Carineta species collected in Goiás State, Brazil. A. Carineta durantoni Boulard, 1986 (CE-UEG no 00336). B. Carineta gemella Boulard, 1986 (CE-UEG no 00159). C. Carineta rufescens (Fabricius, 1803) (CE-UEG no 00331). D. Carineta spoliata (Walker, 1858) (CE-UEG no 00337). Scale $20 \mathrm{~mm}$.

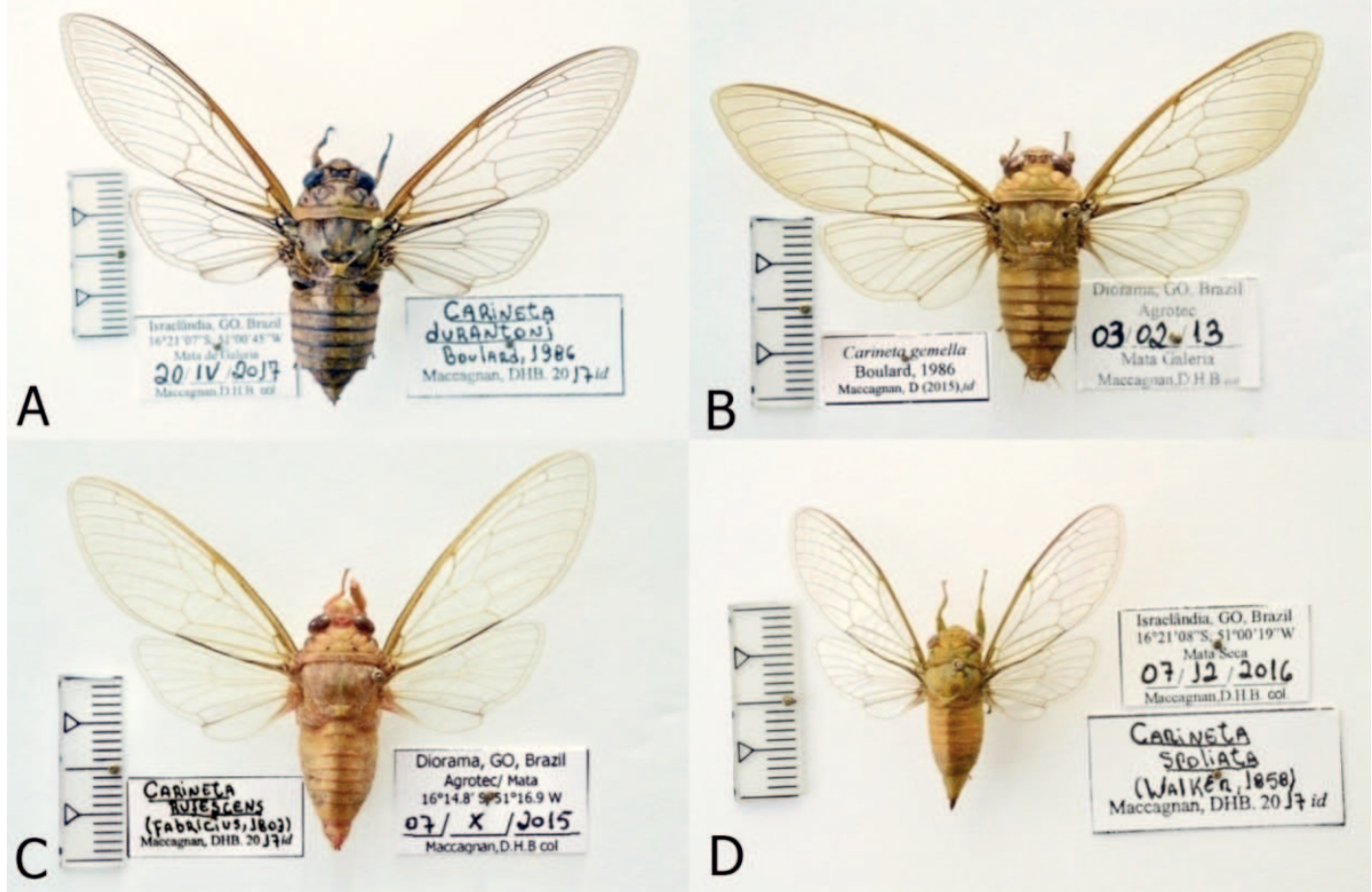

FIGURE 2: Records of occurrence of Carineta durantoni, Carineta gemella, Carineta rufescens and Carineta spoliata. Marks in red represent occurrence in Brazilian states and in black other countries.

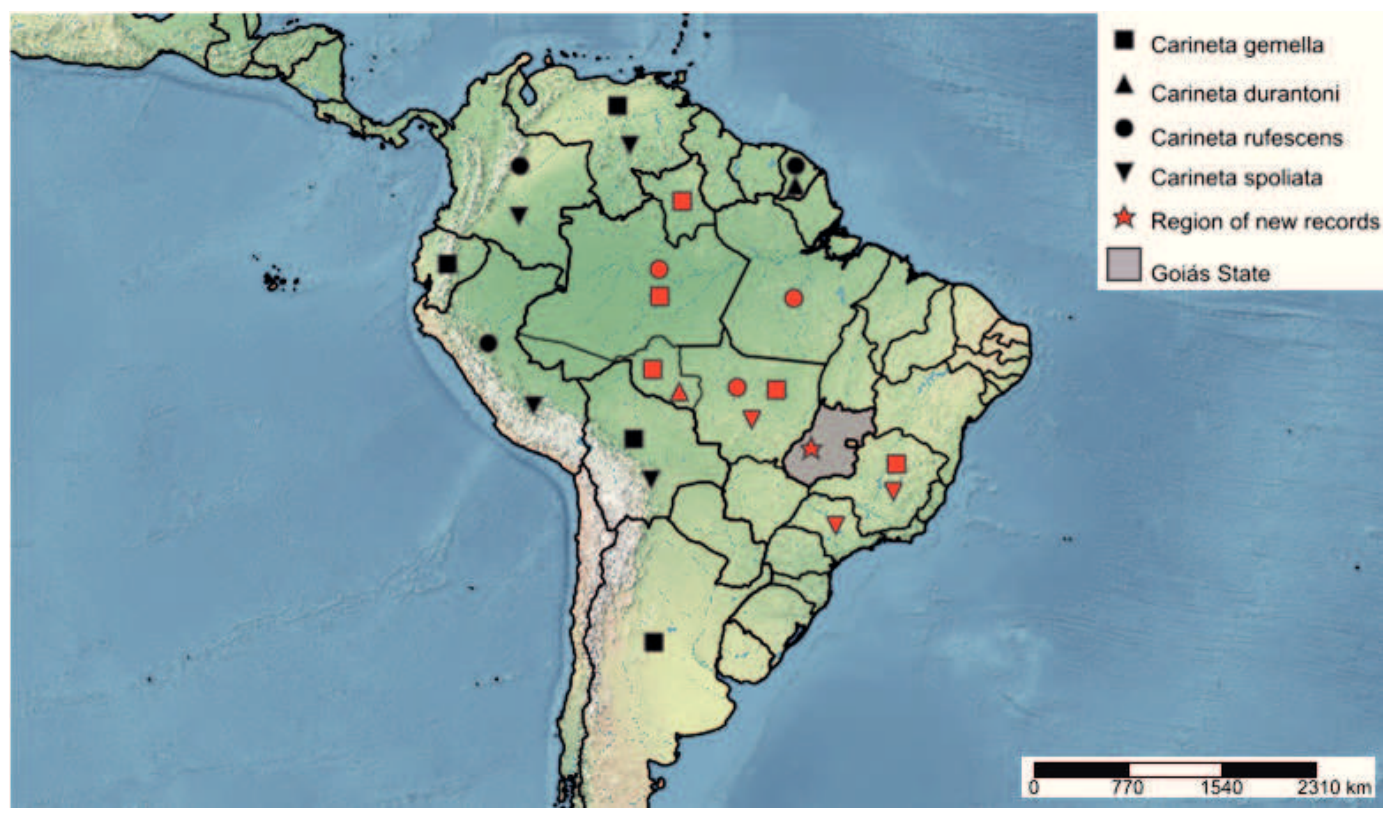


in both sampling localities and was collected in light traps beginning in November and through January. Its occurrence has been reported for Venezuela, Ecuador, Bolivia and Argentina (SANBORN; HEATH, 2014; RUSCHEL; CARVALHO, 2018). In Brazil, this species has been found to occur in the states of Roraima, Amazonas, Rondônia, Mato Grosso and Minas Gerais (SANBORN, 2008; BARRETO; PORFIRO, 2015; RUSCHEL; CARVALHO, 2018).

- Carineta rufescens (Fabricius, 1803) (Figure 1C) We collected three males of $C$. rufescens occurring in both sampling localities in the months of October and November. C. rufescens is easily recognized by the presence of two black marks close to the ambient fissure of the pronotum. Its occurrence has been recorded in French Guiana, Colombia and Peru (SANBORN, 2013). In Brazil, its occurrence was reported in the states of Amazonas, Pará and Mato Grosso (METCALF, 1963; RUSCHEL; CARVALHO, 2018).

- Carineta spoliata (Walker, 1858) (Figure 1D) - We collected four females of C. spoliata in both sampling sites during December and February. This is the smallest of the species collected and characterized by a green color. Its occurrence has been recorded in Venezuela, Colombia, Peru and Bolivia (MARTINELLI; ZUCCHI, 1997; RUSCHEL; CARVALHO, 2018). C. spoliata was previously reported for Brazil in the states of Mato Grosso, Minas Gerais and São Paulo (MARTINELLI; ZUCCHI, 1989; 1997; BARRETO; PORFIRO, 2015; RUSCHEL; CARVALHO, 2018).

In Brazil, most cicadas belonging to the genus Carineta are currently known to occur in the northern region of the country, especially in the state of Amazonas (RUSCHEL; CARVALHO, 2018). In addition to expanding the range of these species, these new records deserve special mention because the localities where the cicadas were collected are situated in the Cerrado biome, which is considered a biodiversity hotspots in which hundreds of endemic species have been under the threat of extinction for some decades (STRASSBURG et al., 2017). Therefore, the results presented here can foster our understanding of how different species of cicadas in Brazil are distributed and thus help in the development of future conservation strategies.

\section{Acknowledgments}

The authors are grateful to Mr. João Batista Peres, Mr. Vilmar Rodrigues Peres and Ms. Solange dos Santos Castro (AGROTEC) for the permit to access the study sites. HCD is grateful to Conselho Nacional de Desenvolvimento Científico e Tecnológico (CNPq), and ARSG and MOD thank the Universidade Estadual de Goiás (UEG) for providing the Scientific Initiation Scholarships. Dr. A. Leyva (USA) helped with English editing of the manuscript.

\section{References}

ALVES, E. D. L. Frequência e probabilidade de chuvas no município de Iporá-GO. Caminhos de Geografia, Uberlândia, v. 12, n. 37, p. 65-72, 2011.

BARRETO, M. R.; PORFIRO, J. M. Espécies de (Hemiptera: Cicadidae) no estado de Mato Grosso, Brasil. EntomoBrasilis, Vassouras, v. 8, n. 3, p. 426-248, 2015.

BOULARD, M. Nouvelles cigales guyano-amazoniennes du genre Carineta (Homoptera, Tibicinidae). Nouvelle Revue d'Entomologie, Paris, v. 2, n. 4, p. 415-429, 1986

CHAMPANHET, J. -M. Nouvelles Carineta de l'Equateur et de Bolivie (Cicadomorpha, Cicadoidae, Tibicinidae). Ecole Pratique dês Hautes Etudes, Travaux Du Laboratoire Biologie et Evolution dês Insects Hemipteroidea, Paris, n. 11/12, p. 65-76, 1999.

DISTANT, W. L. Rhynchotal notes. XXXII. Annals and Magazine of Natural History, London, V. 15, Ser. 7, p. 478-486, 1905.

DISTANT, W. L. A synonymic catalogue of Homoptera. Part I. Cicadidae. London: Trustees of the British Museum, 1906. 207 p.

DUFFELS, J. P.; VAN DER LAAN, P. A. Catalogue of the Cicadoidea (Homoptera, Auchenorhyncha) 1956-1980. Amsterdam: Kluwer Academic Pulishers Group, 1985. 414 p.

MARTINELLI, N. M.; ZUCCHI, R. A. Cigarras associadas ao cafeeiro. IV Gênero Carineta A. \& S., 1843 (Homoptera, Tibicinidae, Tibicininae). Anais da Sociedade Entomológica do Brasil, Londrina, v. 18, p. 13-22, 1989.

MARTINELLI, N. M.; ZUCCHI, R. A. Cigarras (Hemiptera: Cicadidae: Tibicinidae) associadas ao cafeeiro: distribuição, hospedeiros e chave para as espécies. Anais da Sociedade Entomológica do Brasil, Londrina, v. 26, n. 1, p. 133-143, 1997.

METCALF, Z. P. General catalogue of the Homoptera, Fascicle VIII, Cicadoidea. Part 2, Tibicinidae. Raleigh: North Carolina State College Contribution, 1963. 492 p. 
RUSCHEL, T. P.; CARVALHO, G. S. Cicadidae. 2018. Disponível em: <http://fauna.jbrj.gov.br/fauna/faunadobrasil/720>. Acesso em: 10 mar. 2018.

SANBORN, A. F. New records of Brazilian cicadas including the description of a new species (Hemiptera: Cicadoidea, Cicadidae). Neotropical Entomology, Londrina, v. 37, n. 6, p. 685-690, 2008. SANBORN, A. F. Catalogue of the Cicadoidea (Hemiptera: Auchenorrhyncha). London: Academic Press/Elsevier, 2013. $1002 \mathrm{p}$.

SANBORN, A. F. A New genus and new tribe of cicada from South America (Hemiptera: Cicadoidea: Cicadidae) with a note on the taxonomic position of Ahomana Distant, 1905. Proceedings of the Entomological Society of Washington, Washington, v. 116, n. 3, p. 339-348, 2014.

SANBORN, A. F. Generic redescription, two new species, and a key to the species of the cicada genus Ariasa Distant, 1905 with the description of a new genus (Hemiptera: Cicadidae: Cicadinae: Fidicinini). Zootaxa, Auckland, v. 4137, n. 4, p. 501-519, $2016 \mathrm{a}$.

SANBORN, A. F. Five new species, a new genus and a new record of cicadas from French Guiana with four new combinations and three new synonymies (Insecta, Hemiptera, Cicadoidea, Cicadidae). Zoosystema, Paris, v. 38, n. 2, p. 177-199, 2016 b.
SANBORN, A. F. Generic redescription, seven new species and a key to the Taphura Stål, 1862 (Hemiptera: Cicadidae: Cicadetttinae: Taphurini). Zootaxa, Auckland, v. 4324, n. 3, p.451-481, 2017a.

SANBORN, A. F. A new species of Carineta Amyot \& AudinetServille, 1843 (Hemiptera: Cicadoidea: Cicadidae) from Martinique. Proceedings of the Entomological Society of Washington, Washington, v. 119, n. 4, p. 629-636, 2017 b.

SANBORN, A. F.; HEATH, M. S. The cicadas of Argentina with new records, a new genus and fifteen new species (Hemiptera: Cicadoidea: Cicadidae). Zootaxa, Auckland, v. 3883, n. 1, p. 1-94, 2014.

SHORTHOUSE, D. P. SimpleMappr, an online tool to produce publication-quality point maps. 2010. Disponível em: <http:// www.simplemappr.net>. Acesso em: 08 mar. 2018.

STRASSBURG, B. B. N.; BROOKS, T.; FELTRAN-BARBIERI, R.; IRIBARREM, A.; CROUZEILLES, R.; LOYOLA, R.; LATAWIEC, A. E.; OLIVEIRA FILHO, F. J. B.; SCARAMUZZA, C.A. de M.; SCARANO, F. R.; SOARES-FILHO, B.; BALMFORD, A. Moment of truth for the Cerrado hotspot. Nature Ecology \& Evolution, Cambridge, v. 1, article nº 0099, 2017. 